\title{
Evaluation of Syllabus of English for Specific Purposes for Nursing Students
}

\author{
Erlinda Usman ${ }^{1 *}$ and Desvalini Anwar ${ }^{2}$
}

\author{
${ }^{1}$ Universitas Negeri Padang, Padang, Indonesia \\ ${ }^{2}$ Universitas Negeri Padang, Padang, Indonesia \\ *Corresponding author. Email: Fattoning71@gmail.com
}

\begin{abstract}
A syllabus is an important document for teaching which contains the outline of course, including topics, weekly schedule, assignments and tests. A syllabus serves as a communication medium for both theories and practices that will be exposed during study to students. Therefore, it is crucial to evaluate a syllabus to meet the purposes of learning. The subject of this study is the evaluation of the syllabus of English for Specific Purposes in semester 1 for the nursing students and exploration of the needs of the nursing students, professional nurses, and the teaching staff. The study is conducted based on need analysis. Analyzing need analysis is necessary before designing the syllabus to obtain information associated with the nursing students' needs. The method for this study is descriptive and using qualitative approach. The data are obtained through documents, questionnaires, and interviews. The result of the syllabus evaluation of English for Specific Purposes for the nursing students reveals that the syllabus designed for nursing students needs revision to meet the result of need analysis.
\end{abstract}

Keywords: Syllabus, English for Specific Purposes (ESP), Evaluation

\section{INTRODUCTION}

In this competitive era, universities, colleges, and other educational institutions should prepare the students to cope with the needs of future careers. The students need to have knowledge and skills for future employment. They also have to be able to deal with some specific job careers that are available in companies. Being able to communicate in English is one of those skills since English is an international language. Many people with different mother tongues around the world use English to communicate. Having good English communication skills, increase ones' chances of getting good jobs in a national or international company. However, English is one of the obstacles to developing international careers for people who don't speak English as their first language. Hence, English becomes a mandatory subject in many schools and universities.

Nowadays, most schools and universities provide English classes with different purposes for their students. Some of them focus on developing their skills in English in general. When learning English for general purposes, the students learn knowledge and skills of English that can help them to communicate in everyday English conversation. On the other hand, some other schools offer their students to learn English for Specific Purposes (ESP) which contain of different program and purposes. The ESP materials are related to the students' programs, purposes and needs. It can be seen in vocational schools which teach English for Specific Purposes for their students.

The demand for workers with good English skills is increasing in Indonesia significantly. Workers with proficient English is needed to support the private sectors and learning programs in educational institutions. Consequently, the English for Specific Purposes courses/classes ought to equip the students with relevant English skills which can support their professional careers. However, it is unworkable for language learners to instantly learn ESP and master all they need to communicate in their working place. They need to acquire basic English before they learn further for a specific purpose.

Educational institutions need to prepare their students with specific English skills, they have to be ready with an excellent English program. They have to come up with a suitable syllabus and learning materials related to students' needs and their future job needs. Furthermore, Dudley-Evan [1] state ESP figures out what students need to do with English, which skills they need to comprehend, how well they need to understand, and what genres they need to study. Moreover, the proper syllabus designing must by the syllabus designers by selecting the contents and follow the steps of preparing the syllabus to sequence the syllabus items. Several factors to determine in designing the proper syllabus, for instance, the goal suits to the field and the characters of the learners. It is related to Nunan [2] that states 
"difficulty is the key factor in determining the ordering of items in the syllabus".

As stated before, English for Specific Purposes that have been implemented in several nursing schools and faculties should be managed well related to the organized and the proper syllabus designed based on the needs of students. Designing the organized and proper English for Specific Purposes' syllabus for nursing students can give beneficial for students' motivation, future career, and also give value to the institution. The greatest importance is teaching English for Specific Purposes which aim to equip students with adequate English skills and a professional attitude as public servants. Therefore, it is very crucial to achieve the goals by planning an organized, sequenced, and effective syllabus. The organized syllabus is significant to improve the present syllabus prepared by lecturers to be more effective and achievable to accomplish the goals of the learning. Undeniably, the current syllabus is fairly sufficient but not entirely practical in terms of the topic arrangement, and is seemly fairly complicated to achieve the goals of the students. However, the improvement in English for Specific Purposes' syllabus needs to be conducted to cater to the needs of students. Therefore, it requires conducting the need analysis to know the needs of students, targets, and stakeholders. Referring to the phenomena in preparing the English for Specific Purposes' syllabus, conducting a need analysis is significant to evaluate the syllabus to meet the students' needs and be implemented in-class activity. According to Dudley-Evans \& St John [1], a need analysis is generally considered the cornerstone of ESP course design. It is the basis of language learning programs to a focused language learning course and aids the development and improvement of the programs. Conducting need analysis as the first work to collect information and master skills needed based on the work field. Therefore, the teaching and learning process can focus on the important points which become priorities. Need analysis is significant to prepare the ESP suitable syllabus. The syllabus is expecting to offer learning materials that meet the students' needs. Besides, it needs to include language skills and learning activities correlated with their future job.

\section{The Basic Concept of English for Nursing Students}

The teaching and learning of English for "nursing" students are based on the approach of ESP. ESP for nursing students is English for Occupational Purposes which prepares the nursing students with related knowledge and skills to face their future careers and support the main subjects. It is briefly mentioned that English learning aims to equip the students with the English skills for working field or study to relate to needs that support the students' major field study. As stated by Hutchinson and Waters [3], ESP is not a method for learning, but an approach to learning English based on the learner's needs.

English for specific purposes is different from English for general purposes. As stated by Hutchinson and Waters, the implementation of ESP, especially for nursing students focuses on several aspects including English skills, transcultural, and entrepreneurship. These differences are aimed to make the learning process becoming more meaningful, effective, efficient, and relevant to the learners' profession after studying.

The implementation of ESP for nursing students should be managed well related to the organized and the proper syllabus designed based on the needs of students. Designing the organized ESP syllabus for nursing students can give beneficial for students' motivation, future career, and also give value to institutions. The greatest importance is teaching English for Specific which aims to equip students with adequate English skills and a professional attitude as public servants. Therefore, it is very crucial to achieve the goals by planning an organized, sequenced, and effective syllabus. The organized syllabus is significant to improve the present syllabus prepared by lecturers to be more effective and achievable to accomplish the goals of the learning. Undeniably, the current syllabus is fairly sufficient but not entirely practical in terms of the topic arrangement, and is seemly fairly complicated to achieve the goals of the students. However, the improvement in the ESP syllabus needs to be conducted to cater to the needs of students. Therefore, it requires conducting the need analysis to know the needs of students, targets, and stakeholders.

\section{Syllabus}

There are some differences between syllabus and curriculum, otherwise some of them are similar and have similar aims and functions. Westbury [4] states that the syllabus is a guide to the curriculum. The contents of the syllabus are the development of study, goal, schema, content, implementation, and evaluation of the educational system. It is not much different from the curriculum, the syllabus also has similar functions, aims, and even content. Tomlinson [5] states that the development of the syllabus and the materials should be selected and relate to the students' specific needs to meet the purpose of learning.

\section{LITERATURE REVIEW}

There are several studies conducted relating to the need analysis for the ESP program. It can be concluded that conducting need analysis is to prepare the students with qualified skills to study to be accepted in the 
International workplace. The importance of need analysis conducted before designing the syllabus cannot be separated from the development of target needs. Another researcher, Liton [6] mentions that he researches the causes of students' failures to meet the needs in the workplace. He finds that the failure is caused by lack of communication skills. The gap between what students learn in the classroom do not match with the need of the workplace. He studies students of Business Administration at several universities in South-East

The other researcher, Saragih [7], researches with the title "Designing ESP Materials for Nursing Students Based on Need Analysis" in 2014. The study evaluates 50 nursing students in learning English and in designing ESP materials based on need analysis. The results show the needs of nursing students in ESP, lecturers' skills in designing and conducting the syllabus, and the expectation of the professional nurses. The results result are very crucial to conduct that reflects the level of English of the nursing students.

A syllabus contains materials that need to learn by students (what) and know how to learn and achieve the goals (how) [8]. Therefore, a syllabus must contain related information needed by students. One of the results of the study suggested applying the characteristics of a real-world conversation. Research conducts by Bharati, et all [9] with the title "General English I syllabus for intensive language program at IAIN Walisongo". Bharati, et al [9] have redesigning the syllabus and the findings show that the students' need suit to the materials and activities which help them to practice and communicate in English, and also help them to improve their TOEFL result.

\section{Need Analysis}

Since English for nursing is a kind of English for occupational purposes, the syllabus should be based on needs analysis. Need analysis should reveal all aspects of learners' needs in English, for instance, the reasons for learning, knowledge, and skills in English relate to future needs, and deal with different situations.

Dudley Evan and St John [1] state that needs analysis is generally considered the cornerstone of ESP course design. It is the basis of language learning programs, which leads to a focused language learning course and aids the development and improvement of the programs. Another perception of needs analysis is gathering relevant information systematically that meets the requirement in language learning, within the context of certain institutions involved in learning situations [9].

As stated by Miyake and Tremarco [10], there are two instruments used to know the needs of groups of students. These two instruments, questionnaires and interviews are applied to conduct need analysis It refers to build the how and what of course. The conclusion of need analysis is a process of gaining and assessing the how and what of course. The information is about learners' data, such as the students' goals and backgrounds, language levels, why they are taking the course, their preferences of teaching and learning, and the situations they will communicate in. Referring to the statement above, it is crucial to conduct need analysis that focuses on its roles and as a guide for designing course, the syllabus, and do the evaluation.

As stated by Brown [11] that need analysis is the well-organized process of collecting and analyzing the data needed to design the appropriate syllabus to cater to the need of students. Furthermore, this process aims to know the needs and the desire of the learners [12]. As mentions above that need analysis is a process of gathering information about the students, learning needs, wants, etc. However, an issue in the students' needs analysis is that sometimes the students do not know what they need. The students are not able to find their own needs [13]. Moreover, Hyland [14] defines that need analysis is the technique of how the needs of learners collected and assessed to design a suitable syllabus.

\section{Evaluation}

The purpose of conducting the evaluation is to know whether the syllabus needed to be change or modify. To obtain feedback on the implementation of English for Specific Purposes and the syllabus, it is needed to evaluate several areas. Evaluation will show the weaknesses or the strength of the particular group of learners[1]. Therefore, it is very important to evaluate to help identify the problem areas and shortcomings, if any.

\section{METHOD}

This research emphasizes the need analysis which uses a descriptive with a qualitative approach. The subject of the research was Evaluation of the syllabus of ESP of semester 1 for nursing students. The researcher used two techniques in data collection, including questionnaires and interviews. For interviews, the researcher used semi-structured interviews which contain several questions as guidance and the questions was able to develop to find related information. The second technique was an interview. The researcher interviewed several lectures with provided questions and develop them to find out the main problem and related information. Similar to the professional nurses, the researcher also conducted semi-structure interviews which contain provided questions as guidance and were able to develop these questions to gain related information.

5 points of Likert scales were used to describe the result of students' needs analysis. 5 Option were used in 
the first questionnaires are "Strong Important", "Important", "Adequate Important",, "Less Important", and "Not Important"

The means intervals for the Likert scale and the categories are as follows:

Table 1 Likert Scale Interval

\begin{tabular}{|c|c|c|}
\hline Scale & Mean Interval & Category \\
\hline 1 & $4.51-5.00$ & $\begin{array}{c}\text { Strong } \\
\text { Important }\end{array}$ \\
\hline 2 & $3.51-4.50$ & Important \\
\hline 3 & $2.51-3.50$ & $\begin{array}{c}\text { Adequate } \\
\text { Important }\end{array}$ \\
\hline 4 & $1.51-2.50$ & Less Important \\
\hline 5 & $1.00-1.50$ & Not Important \\
\hline & & \\
\hline
\end{tabular}

\section{RESULTS AND DISCUSSION}

The analysis result showed that the students need to learn more topics to adjust themselves in any situation and master communication skills to support them to get better careers in the future. The students also must master four skills in English to increase their English proficiency, support their knowledge, and can cater to the demand of professional nurses in the future.

Table 2 English skills needed in the workplace

\begin{tabular}{|l|l|c|c|}
\hline \multicolumn{2}{|c|}{ Topics } & $\begin{array}{c}\text { Mean } \\
\text { Value }\end{array}$ & Category \\
\hline 1 & Speaking & 4.90 & Very Often \\
\hline 2 & Listening & 4.90 & Very Often \\
\hline 3 & Writing & 4.50 & Often \\
\hline 4 & Reading & 4.40 & Often \\
\hline
\end{tabular}

Analyzing some topics/contents of syllabus related to the skills are crucial. The result of the analysis for each skill are shown as follows: (Table 3)

Table 3 The category of topics related to the skills needed in the ESP syllabus

\begin{tabular}{|c|c|c|c|c|c|}
\hline \multirow{2}{*}{\multicolumn{2}{|c|}{ Topics }} & \multirow{3}{*}{$\begin{array}{c}\text { Mean } \\
\text { Value }\end{array}$} & \multirow{3}{*}{$\begin{array}{c}\text { Category } \\
\text { Strong } \\
\text { Important }\end{array}$} & \multicolumn{2}{|c|}{ Purpose } \\
\hline & & & & Academic & Occupational \\
\hline 1 & Social skills & & & & $\sqrt{ }$ \\
\hline 2 & Cultural differences & 4.80 & $\begin{array}{c}\text { Strong } \\
\text { Important }\end{array}$ & & $\sqrt{ }$ \\
\hline 3 & Interpreting medical terms & 4.80 & $\begin{array}{l}\text { Strong } \\
\text { Important }\end{array}$ & $\sqrt{ }$ & $\sqrt{ }$ \\
\hline 4 & Presentation skills & 4.70 & Important & & $\sqrt{ }$ \\
\hline 5 & Giving advice & 4.40 & $\begin{array}{l}\text { Adequate } \\
\text { Important }\end{array}$ & $\sqrt{ }$ & $\sqrt{ }$ \\
\hline 6 & Report writing & 4.00 & Important & $\sqrt{ }$ & $\sqrt{ }$ \\
\hline 7 & $\begin{array}{l}\text { Reading and interpreting reports, prescriptions, charts, } \\
\text { others. }\end{array}$ & 4.00 & Important & & $\sqrt{ }$ \\
\hline
\end{tabular}

The contents/topics were categorized, based on students' needs analysis result, as very important. Besides mastering its knowledge, the nursing students had to adjust themselves in any situation, for instance, they are needed as trauma healing teams which meet the victims of natural disaster or other psychology cases. The students also must understand cultural differences, since the students are prepared to work abroad. These topics could be taken into consideration to put in the ESP syllabus.

\section{CONCLUSION}

Based on the result and discussion above, there were some conclusions can be drawn. The first, the ESP syllabus was an integrated syllabus that combination of the knowledge, skill, and social interaction related to the nursing contents. Second, it was very crucial to conduct need analysis to fulfill the students' needs and meet the future needs. The nursing characters, values of caring, respect, responsibility, and kindness need to contribute to the syllabus. Best of all, the syllabus of ESP for nursing students will support the nursing schools/universities in producing qualified graduates. 


\section{REFERENCES}

[1] [1] D. Evan \& St John, "A Multi-disciplinary Approach", in Developments of ESP, Cambridge: Cambridge University Press, 1988.

[2] D. Nunan, Syllabus Design. New York: Oxford University Press, 1988.

[3] T. Hutchinson \& A. Water," A Learning-Centered Approach", in English for Specific Purposes. Cambridge: Cambridge University Press, Isaac, Stephen, 1992.

[4] I. Westbury, "Making Curricula, Why Do States Make Curricula and How ?," in The Sage Handbook Of Curriculum And Instruction, F.M Connelly, M.F He \& J. Phillion, Ed., Thousand Oaks, CA, Sage, pp. 45-65, 2008.

[5] B. Tomlinson, Developing Materials for Language Teaching. Newyork, 2013.

[6] H.A Liton, "ESP Learners's Needs Related Learning for the Workplace: A Pragmatic Study for Business School," Int.J.Instr., vol.8,no.2,pp. 4$16,2015$.

[7] E. Saragih," Designing ESP Materials for Nursing Students Based on Need Analysis," in International

Journal of Linguistics, Vol 6 No 4, August 2014, pp.59-70, 2014.
[8] J.D. Brown, "The Element of Language Curriculum: A Systematic Approach to Program Development." Boston: Heinle \& Heinle Publisher, 1995.

[9] Bharati and D. A Linggar, et al. "Redesigning General English I Syllabus for Intensive Language Program", in English Education Journal 3 (2), pp.78-84, 2013.

[10] M. Miyake and J. Tremarco," Needs Analysis for Nursing Students Utilizing Questionnaires and Interviews," Journal of Medical Welfare, 11 (1), pp. 22-34, Kawasaki University of Medical Welfare, 2005.

[11]J. D. Brown." Introducing Needs Analysis and English for Specific Purposes," Abingdon. Routledge, 2016.

[12]I.S.P Nation and J. Macalister, Language Curriculum Design. New York: Routledge, 2010.

[13] G. Kavaliauskiene \& D. Uzpalience, "Ongoing Needs Analysis as a Factor to Successful Learning," Journal of Language and Learning, 1 (1), pp. 1-6, 2003.

[14]K. Hyland, "English for Academic Purposes-An Advanced Resources Book,". New York: Routledge. Applied Linguistics, 2006. 